\title{
Operation for anorexigen-associated valvular heart disease
}

James A. Caccitolo, MD

Heidi M. Connolly, MD

David S. Rubenson, MD

Thomas A. Orszulak, MD

Hartzell V. Schaff, MD

From the Divisions of Cardiovascular Surgery and Cardiovascular Diseases and Internal Medicine, Mayo Clinic, Rochester, Minn, and the Division of Cardiovascular Diseases, Scripps Clinic, La Jolla, Calif.

Received for publication Oct 6, 2000; revisions requested Jan 17, 2001; revisions received April 2, 2001; accepted for publication April 5, 2001.

Address for reprints: Hartzell V. Schaff, MD Mayo Clinic, 200 First Street SW, Rochester, MN 55905.

J Thorac Cardiovasc Surg 2001;122:656-64

Copyright (C) 2001 by The American Association for Thoracic Surgery

0022-5223/2001 $\$ 35.00+0 \quad \mathbf{1 2 / 1 / 1 1 6 3 1 5}$

doi:10.1067/mtc.2001.116315
Objectives: Recently, valvular regurgitation has been observed in patients who have taken fenfluramine or dexfenfluramine with or without phentermine. This study describes the clinical, echocardiographic, and pathologic findings of anorexigenassociated valvular heart disease and the surgical interventions required to treat it.

Methods: We reviewed clinical information on 14 patients with severe anorexigenassociated valvular disease who underwent cardiac operations.

Results: Thirteen women (mean age $44.2 \pm 5.3$ years) received fenfluramine, 58.5 $\pm 22.3 \mathrm{mg} /$ day, and phentermine, $32.1 \pm 11.4 \mathrm{mg} /$ day, for an average of $12.1 \pm 7.3$ months before presentation. One woman received dexfenfluramine, $30 \mathrm{mg} /$ day for 13 months, and phentermine, $60 \mathrm{mg} / \mathrm{day}$, concomitantly for 6 months. Presenting symptoms included dyspnea (12 cases), palpitations (3), and atypical chest pain (3). Six patients had heart failure, and 4 had a new murmur. Echocardiography demonstrated severe mitral valve regurgitation in all patients. Seven also had aortic regurgitation, and 4 had significant tricuspid regurgitation. Four patients had successful mitral valve repair, 1 with concomitant aortic valve repair. Ten additional patients eventually required mitral valve replacement, 5 with concomitant aortic valve replacement. Excised valves demonstrated a glistening white appearance with plaque-like encasement of leaflets and chordae. Focal surface proliferation and fibrosis with a "stuck-on" appearance was consistently found.

Conclusions: Anorexigen use may lead to severe multivalvular regurgitation with characteristic echocardiographic and pathologic findings. Recognition of druginduced valvulopathy is important because of widespread use of these medications and the uncertain natural history of the disease. Early surgical experience suggests that valve repair is possible in these young patients.

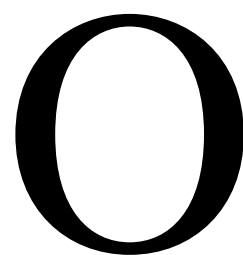

besity is a medical problem in the United States that affects 58 million people. Despite the estimated 33 billion dollars spent each year by consumers in the United States on diet products and programs, ${ }^{1}$ the incidence of obesity rose from $25 \%$ in 1980 to $33 \%$ in 1991. ${ }^{2}$ Obesity contributes directly to increases in related health complications, such as adult-onset diabetes, ${ }^{3}$ heart disease, and hypertension, with estimated medical costs of nearly 40 billion dollars a year. ${ }^{4}$

Many weight-loss methods are ineffective, but in prospective trials, prescription anorectics such as fenfluramine and phentermine (Figure 1) produced significantly greater weight loss than did placebo medications. ${ }^{5}$ The combined use of fenfluramine and phentermine was proposed in 1984 by Weintraub and associates. ${ }^{6}$ Dexfenfluramine, the D-isomer of fenfluramine, was approved for use in the United States in April 1996, and in that same year, more than 18 million 


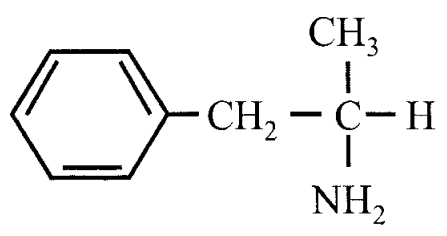

amphetamine

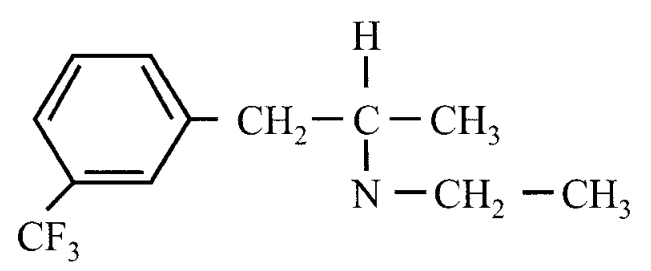

fenfluramine

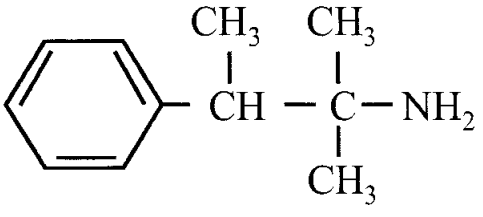

phentermine

Figure 1. Structures of amphetamine, fenfluramine, and phentermine.

monthly prescriptions were written in this country for the three popular anorexigens fenfluramine, dexfenfluramine, and phentermine. ${ }^{7}$

In July 1997, a report called attention to a possible association, in 24 patients, between a unique type of valvular heart disease and the use of diet medications. ${ }^{8}$ By September 1997, more than 100 cases of anorexigen-associated valvular disease had been reported to the Food and Drug Administration (FDA), including those of 21 patients who required cardiac surgery for treatment of their disease. The pathophysiologic mechanism and the natural history of anorexigen-associated valvular disease remain unknown. To define common characteristics among patients with this disease and to suggest a plan for management of patients requiring surgical intervention, we report this review of 14 of the 21 known surgical patients.

\section{Methods}

Between May 1996 and April 1997, valvular heart disease was identified in 24 women who had taken the drug combination fenfluramine and phentermine. ${ }^{8}$ In this group, 5 patients required repair or replacement of diseased heart valves. After this initial description, other cases of valvular disease were reported to our institution from physicians nationwide, and a database was established to document identified cases. From a database of 175 patients with suspected anorexigen-associated valvular disease, we found a total of 14 patients (including the original 5) who had cardiac surgery for treatment of severe valvular heart disease; these patients had operations at 9 different institutions. All available diagnostic test reports and patient records were reviewed. In cases missing specific data, patients were contacted directly.

\section{Results}

The characteristics of the 14 women (mean age $44.2 \pm 5.3$ years) and their evaluations, treatments, and findings are presented in Tables 1 and 2. Preoperatively, 13 women were prescribed fenfluramine (mean dosage $58.5 \pm 22.3 \mathrm{mg} /$ day) and phentermine $(32.1 \pm 11.4 \mathrm{mg} /$ day $)$ for an average duration of $12.1 \pm 7.3$ months. One woman received dexfenfluramine (30 mg/day) for 13 months with phentermine (60 $\mathrm{mg} /$ day) concomitantly for 6 months. The average body mass index (weight in kilograms/height in meters squared) of the surgical patients before initiation of diet drug therapy was $31.6 \pm 4.7 \mathrm{~kg} / \mathrm{m}^{2}$.

Before they began taking diet drugs, 13 of the 14 women had no history of cardiac disease and had normal cardiac findings as part of their general physical examinations. One patient had scarlet fever as a child but with no known cardiac complications and with normal cardiac examinations as an adult. None of the patients had echocardiograms documenting the absence of valvular heart disease before initiation of anorexigen therapy. After diet drug usage, however, all 14 patients had severe valvular disease that could not be attributed to any other cause. The most common symptom, for which 12 patients (85\%) saw a physician, was dyspnea. Three patients reported palpitations $(21 \%)$, and 3 described atypical chest pain. At presentation, 7 patients were noted to be in congestive heart failure on the basis of physical examination and chest $\mathrm{x}$-ray films. In addition, 4 patients had a new, prominent murmur that was identified on their initial physical examination.

Preoperative echocardiography demonstrated severe mitral valve regurgitation in all patients, and $7(50 \%)$ patients also had severe aortic valve regurgitation; 4 had moderate or greater tricuspid valve regurgitation. The characteristic echocardiographic findings included thickened valve leaflets tethered by shortened and thickened chordae. ${ }^{8}$ The valve structure noted by echocardiography was similar to features of chronic rheumatic involvement but without 
TABLE I. Patient characteristics

\begin{tabular}{|c|c|c|c|c|c|c|}
\hline \multirow[b]{2}{*}{ Case } & \multicolumn{4}{|c|}{ Demographics } & \multirow[b]{2}{*}{ BMI $\left(\mathrm{kg} / \mathrm{m}^{2}\right)$} & \multirow{2}{*}{$\begin{array}{c}\text { Medical history } \\
\text { Other medications }\end{array}$} \\
\hline & Age (y) & Sex & Weight (kg) & Height (cm) & & \\
\hline 1 & 48 & $\mathrm{~F}$ & 85 & 157 & 34.5 & Sertraline, hydrochlorothiazide \\
\hline 2 & 44 & $\mathrm{~F}$ & 91 & 160 & 35.5 & $\begin{array}{l}\text { Lisinopril, conjugated estrogens, } \\
\text { theophylline }\end{array}$ \\
\hline 3 & 50 & $\mathrm{~F}$ & 96 & 158 & 38.5 & Nortriptyline, propylthiouracil \\
\hline 4 & 41 & $\mathrm{~F}$ & 108 & 165 & 39.7 & None \\
\hline 5 & 52 & $\mathrm{~F}$ & 69 & 158 & 27.6 & Fluoxetine \\
\hline 6 & 40 & $\mathrm{~F}$ & 82 & 167 & 29.0 & None \\
\hline 7 & 44 & $\mathrm{~F}$ & 89 & 168 & 31.7 & Ranitidine \\
\hline 8 & 41 & $\mathrm{~F}$ & 71 & 152 & 30.7 & None \\
\hline 9 & 51 & $\mathrm{~F}$ & 80 & 158 & 32.2 & Conjugated estrogens \\
\hline 10 & 44 & $\mathrm{~F}$ & 88 & 160 & 34.3 & Pirbuterol acetate, triamcinolone \\
\hline 11 & 37 & $\mathrm{~F}$ & 74 & 163 & 28.0 & None \\
\hline 12 & 46 & $\mathrm{~F}$ & 84 & 162 & 32.0 & Enalapril, lansoprazole, sulfacetamide \\
\hline 13 & 34 & $\mathrm{~F}$ & 63 & 165 & 23.5 & Prednisone \\
\hline 14 & 47 & $\mathrm{~F}$ & 68 & 163 & 25.6 & Lisinopril, furosemide, zolpidem \\
\hline Mean \pm SD & $44.2 \pm 5.3$ & & $82.0 \pm 12.3$ & $161.1 \pm 4.4$ & $31.6 \pm 4.7$ & \\
\hline
\end{tabular}

$B M I$, Body mass index; $S D$, standard deviation

TABLE 2. Summary of evaluations, treatments, and findings

\begin{tabular}{|c|c|c|c|}
\hline Case & Presentation & Echocardiography & Catheterization \\
\hline 1 & Dyspnea, edema & Severe MR, moderate AR & $\begin{array}{l}\text { Severe MR, normal coronaries, } \\
\text { PAP } 35 / 16 \mathrm{~mm} \mathrm{Hg}\end{array}$ \\
\hline 2 & CHF, dyspnea, murmur & Severe AR and MR, moderate TR, EF $40 \%$ & Severe AR and MR, PAP $55 / 31 \mathrm{~mm} \mathrm{Hg}$ \\
\hline 3 & Dyspnea & Severe MR, RVSP 52 mm Hg & Moderate MR, EF 50\% \\
\hline 4 & Dyspnea, murmur & Severe MR, thickened MV & Severe MR, normal coronaries \\
\hline 5 & CHF, murmur, dyspnea & Severe MR, RVSP $75 \mathrm{~mm} \mathrm{Hg}$ & Normal coronaries \\
\hline 7 & Dyspnea, chest pain & $\begin{array}{l}\text { Moderate MR, AR, valves structurally normal, } \\
\text { chamber dimensions normal }\end{array}$ & $\begin{array}{l}\text { Severe MR, AR, normal coronaries, } \\
\text { EF } 70 \%, \text { PAP } 70 / 18 \mathrm{~mm} \mathrm{Hg}\end{array}$ \\
\hline 8 & Dyspnea, CHF & $\begin{array}{l}\text { Severe MR, AR, thickened MV leaflets, fixed } \\
\text { post. leaflet; PAP } 64 \mathrm{~mm} \mathrm{Hg}\end{array}$ & Normal coronaries, severe MR \\
\hline 9 & Dyspnea, CHF & Severe MR, moderate AR & $\begin{array}{l}\text { AR and MR, normal coronaries, } \\
\text { normal LV function }\end{array}$ \\
\hline 12 & Hemoptysis, palpitations & $\begin{array}{l}\text { Severe MR, thickening of both mitral leaflets with } \\
\text { tethering of posterior, dilated LV, PAP } 31 \mathrm{~mm} \mathrm{Hg}, E F 60 \%\end{array}$ & $\begin{array}{l}\text { Normal coronaries, severe MR, } \\
\text { PAP } 60 / 40 \mathrm{~mm} \mathrm{Hg}\end{array}$ \\
\hline 13 & Dyspnea, palpitations & Severe MR & $\begin{array}{l}\text { Severe MR, normal LV function, } \\
\text { normal coronaries }\end{array}$ \\
\hline 14 & Dyspnea, CHF & $\begin{array}{l}\text { Severe MR, TR; mild AR, thickened mitral, aortic, } \\
\text { tricuspid leaflets, tethering of post. mitral leaflet, } \\
\text { dilated LV, EF } 57 \% \text {, PAP } 41 \mathrm{~mm} \mathrm{Hg}\end{array}$ & Normal coronaries \\
\hline
\end{tabular}

$C H F$, Congestive heart failure; $M R$, mitral regurgitation; $A R$, aortic regurgitation; $T R$, tricuspid regurgitation; $E F$, left ventricular ejection fraction; $R V S P$, right ventricular systolic pressure; $M V$, mitral valve; ant., anterior; post., posterior; $L A$, left atrium; $P A P$, pulmonary artery pressure; $L V$, left ventricle; $P C W P$, pulmonary capillary wedge pressure; $R C A$, right coronary artery; $M V R$, mitral valve replacement; $A V R$, aortic valve replacement; $T V$, tricuspid valve; $A V$, aortic valve; $N A$, not available. 


\begin{tabular}{lccc}
\hline \multicolumn{1}{c}{ Medical history } & \multicolumn{3}{c}{ Appetite suppressant use } \\
\cline { 1 - 4 } Results of previous cardiac examination & Phentermine (mg/d) & Fenfluramine (mg/d) & Duration (mo) \\
\hline Normal & 30 & 60 & 9 \\
Normal & 30 & 60 & 12 \\
Normal & 30 & 60 & 11 \\
Normal & 48 & 120 & 25 \\
Normal & 15 & 40 & 12 \\
Normal & 30 & 60 & 24 \\
Normal & 15 & 60 & 3 \\
Normal & 37 & 20 & 6 \\
Normal & 34 & 40 & 6 \\
Normal & 30 & 60 & 5 \\
Normal & 30 & 60 & 12 \\
Normal (scarlet fever at 1 y), all cardiac exams normal & 30 & 60 & 7 \\
Normal & 30 & 60 & 24 \\
Normal & 60 & Dexfenfluramine 30 & 13 Dex, 6 Phen \\
& $32.1 \pm 11.4$ & $58.5 \pm 22.3$ & $12.4 \pm 7.5$ \\
\hline
\end{tabular}

\begin{tabular}{|c|c|c|}
\hline Procedure & Operative findings & Pathologic findings \\
\hline MVR, AVR & No prolapse or chordal rupture & "Stuck-on plaque" on leaflets \\
\hline MVR, AVR, TV repair & No chordal rupture or flail segment trileaflet AV & "Stuck-on plaque" on leaflets \\
\hline MVR & Glistening white, thickened leaflets and chordae & "Stuck-on plaque" on leaflets \\
\hline MV repair & Glistening white, thickened, tethered leaflets & NA \\
\hline MV repair & Distinctly unusual—post. leaflet, thickened, tethered & NA \\
\hline Attempted repair, MVR & $\begin{array}{l}\text { Avulsion of central cusp of post. leaflet with ruptured } \\
\text { chordae, elongated and torn ant. leaflet chordae }\end{array}$ & $\begin{array}{l}\text { White-gray glistening valve cusps, focally thickened } \\
\text { chordae, consistent with myxoid valvulopathy }\end{array}$ \\
\hline MVR, AVR & Post. leaflet prolapse & Focal myxoid changes \\
\hline MVR, AVR & Small post. leaflet, fused chordae, fixed ant. leaflet & Thickened chordae \\
\hline MV and AV repair & Mitral annular dilatation & NA \\
\hline MVR, AVR & Thickened valve, thickened, tethered chordae & $\begin{array}{l}\text { Thickened leaflets and } \\
\text { chordae }\end{array}$ \\
\hline Attempted repair, MVR & $\begin{array}{l}\text { Thickening with retraction and scarring, chordae } \\
\text { primarily shortened, primary defect in mid-post. leaflet }\end{array}$ & Glistening thickening of leaflets and chordae \\
\hline MV repair & Glistening white, thickened, tethered leaflets & NA \\
\hline $\begin{array}{l}\text { Attempted, } \\
\text { repair, MVR }\end{array}$ & Thickening of chordae, malcoaptation of leaflets & Mitral leaflet biopsy: normal mitral valve leaflet \\
\hline MVR & $\begin{array}{l}\text { Retraction of the post. leaflet with tethering and } \\
\text { shortened, fibrosed chordae }\end{array}$ & $\begin{array}{l}\text { Mild focal leaflet and chordal thickening due to } \\
\text { focal surface proliferation; "stuck-on" appearance }\end{array}$ \\
\hline
\end{tabular}




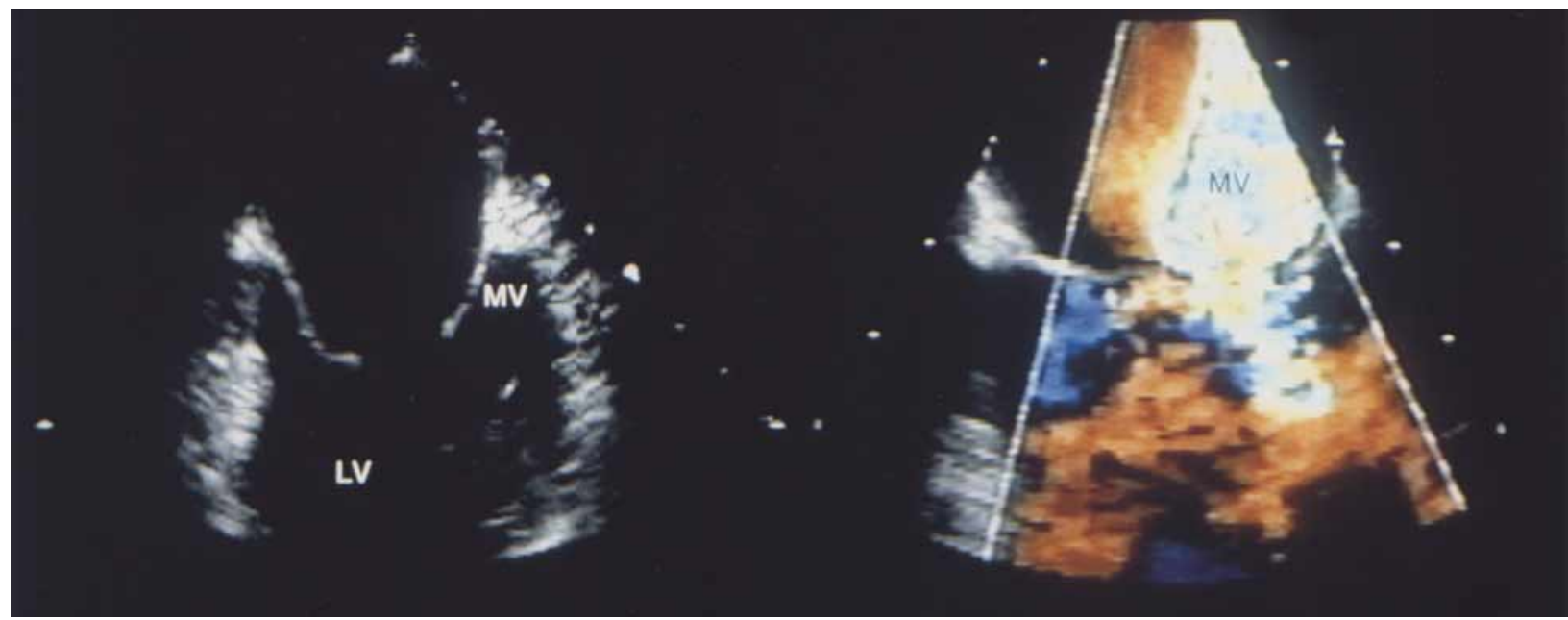

Figure 2. Representative echocardiographic views of a mitral valve affected by anorexigen use. The left image demonstrates the thickened valve leaflets, and the right shows severe mitral regurgitation. $L V$, Left ventricle; $M V$, mitral valve.

\section{TABLE 3. Comparison of valvulopathies}

\begin{tabular}{|c|c|c|}
\hline & Common positions & Echocardiography \\
\hline Rheumatic & Mitral, aortic & Thickened, hypomobile leaflets, MR, AR, AS \\
\hline Ergot $^{35}$ & Mitral, aortic & $\begin{array}{l}\text { Thickened, hypomobile to nonmobile leaflets with variable stenosis } \\
\text { and regurgitation }\end{array}$ \\
\hline Methysergide 36,37 & Aortic, mitral & Thickened leaflets, MR \\
\hline Carcinoid 38 & Tricuspid, pulmonary & $\begin{array}{l}\text { Thickened leaflets with valvular stenosis and regurgitation, hypomobile } \\
\text { or nonmobile leaflets with shortening of chordae }\end{array}$ \\
\hline Diet drug & Mitral, aortic, tricuspid & $\begin{array}{l}\text { Atypical for rheumatic, congenital, or degenerative lesions, thickening } \\
\text { of leaflets and chordae, fixation of posterior MV leaflets, no obstruction }\end{array}$ \\
\hline
\end{tabular}

$M R$, Mitral regurgitation; $A R$, aortic regurgitation; $A S$, aortic stenosis; $M V$, mitral valve.

commissural fusion and stenosis. The anterior mitral leaflet appeared thickened, with diastolic doming and retained mobility. The posterior mitral leaflet tended to be thickened with decreased mobility. The chordae tendineae were also thickened and shortened and caused tethering of the posterior leaflet; 1 patient also had chordal rupture. Echocardiographic features of aortic valve involvement included thickened and retracted valve cusps. Involved tricuspid valves also demonstrated thickening with variable fixation of the septal leaflet and decreased mobility of the anterior leaflet (Figure 2). Left ventricular function was decreased in only 1 patient (ejection fraction $40 \%$ ).

All 14 patients underwent preoperative cardiac catheterization. Results of coronary angiography were normal in 13 patients; 1 patient (40 years old) had $60 \%$ narrowing of the ostium of the right coronary artery. Pulmonary hypertension was found at cardiac catheterization in 6 patients (mean pulmonary artery pressure $35.3 \pm 10.6 \mathrm{~mm} \mathrm{Hg}$ ). Five of the 14 patients initially underwent a mitral valve repair, and of these, 1 had concomitant aortic valve repair. At the time of the initial operation in 2 patients, repair of the mitral valve was attempted and then abandoned for prosthetic replacement. Seven patients underwent mitral valve replacement as an initial procedure, 5 with concomitant aortic valve replacement. At operation, diseased valves were described as having a glistening white appearance without the yellowish discoloration or calcification that is often seen in rheumatic heart disease (Figure 3). Valve leaflets and chordae with the glistening white coating tended to have decreased mobility because of both leaflet thickening and 

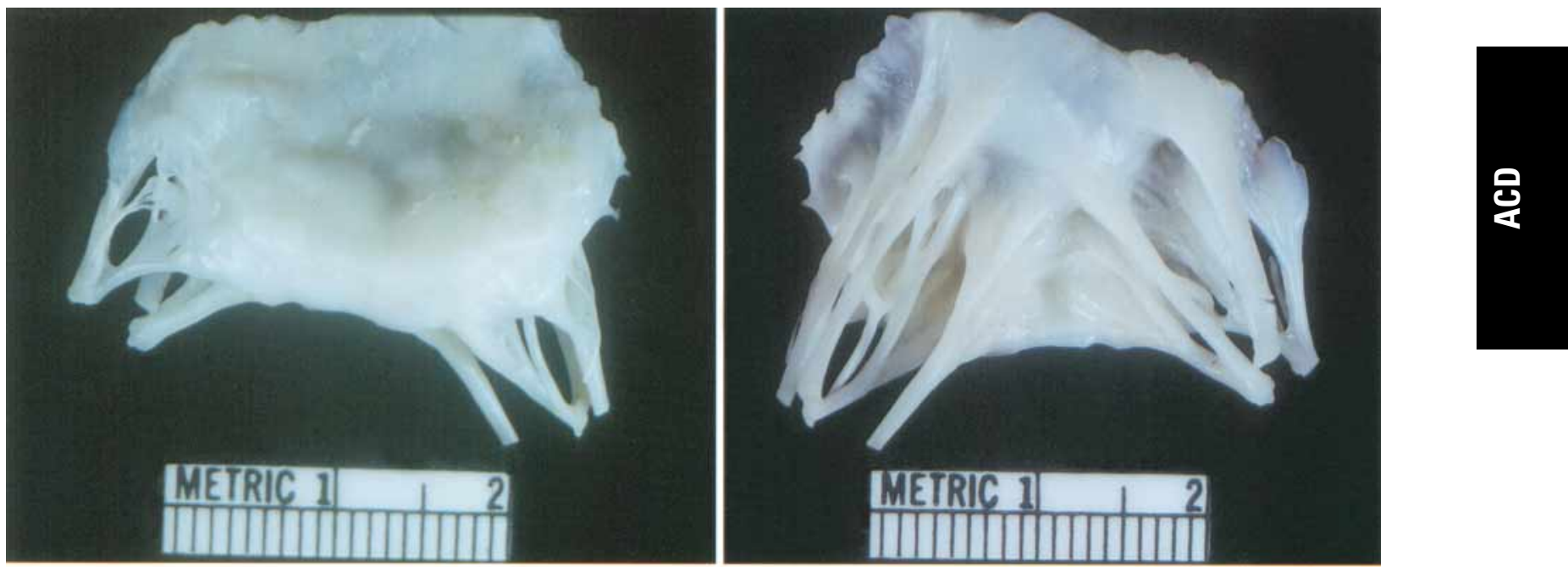

Figure 3. Photographs of valve excised from a patient exposed to fenfluramine and phentermine. Of note is the glistening, pure-white appearance and thickening of the valve leaflets and chordae. Left, Viewed from the left atrium. Right, Viewed from the left ventricle.

\begin{tabular}{cc}
\hline \multicolumn{1}{c}{ Gross appearance } & Histology \\
\hline $\begin{array}{l}\text { White, thickened fibrotic valve leaflets, nodules, } \\
\text { calcifications, fused commissures }\end{array}$ & $\begin{array}{c}\text { Dense fibrovascular, postinflammatory tissue, } \\
\text { Aschoff nodules, calcifications }\end{array}$ \\
$\begin{array}{c}\text { White thickening and encasement of valve leaflets } \\
\text { and chordae }\end{array}$ & $\begin{array}{c}\text { Proliferation of smooth-muscle cells and fibroblasts, } \\
\text { avascular collagen matrix encasing leaflets and chordae, little } \\
\text { destruction of normal underlying structures }\end{array}$ \\
$\begin{array}{c}\text { Uniform glistening white thickening of leaflets and chordae, } \\
\text { fusion of commissures and chordae }\end{array}$ & $\begin{array}{c}\text { Avascular, poorly cellular fibrous tissue without elastic fibers, } \\
\text { myocardial fibrosis }\end{array}$ \\
"Pearly white" thickening of leaflets and chordae & $\begin{array}{c}\text { Smooth-muscle cell proliferation without elastic fibers, plaques adherent } \\
\text { sometimes involving chambers }\end{array}$ \\
$\begin{array}{c}\text { Glistening white leaflets and chordae with diffuse } \\
\text { thickening, no calcifications, shortening of chordae with }\end{array}$ & "Stuck-on" plaques, proliferative myelofibroblasts in an abundant \\
tethering of posterior MV leaflet & extracellular matrix
\end{tabular}

tethering by shortened chordae. As noted on the echocardiogram, 1 patient had chordal rupture. Microscopy demonstrated characteristic plaque-like encasement of the leaflets and chordal structures. The elastic-van Gieson stain demonstrated smooth muscle cell hyperplasia in an abundant extracellular matrix. This focal surface proliferation and fibrosis was seen without evidence of inflammation or damage to the underlying valve structure, giving the lesions a "stuckon" appearance (Figure 4).

There was no early or late mortality among the 14 patients in this series who underwent surgery. One patient who initially underwent valve replacement elsewhere required early reoperation for bleeding. Additionally, 2 years after valve repair, that same patient required valve replacement for recurrent severe mitral regurgitation (patient 13, Table 1). The 4 other patients who underwent mitral valve repair are well 24 to 38 months after repair, with no evidence of progression of valvular disease. All patients who underwent valve replacement are well, now 12 to 36 months postoperatively.

\section{Discussion}

Fenfluramine was developed in 1962 by Beregi and associates, ${ }^{9}$ through a trifluromethyl substitution of amphetamine, in an effort to produce a drug with the same anorectic effects but with fewer stimulatory side effects than the parent compound. In the central nervous system, fenfluramine causes the release of serotonin ${ }^{10}$; however, it also has direct effects on metabolism by increasing muscle glucose uptake ${ }^{11}$ and inhibiting lipogenesis. ${ }^{12}$ The primary complication associated with the 

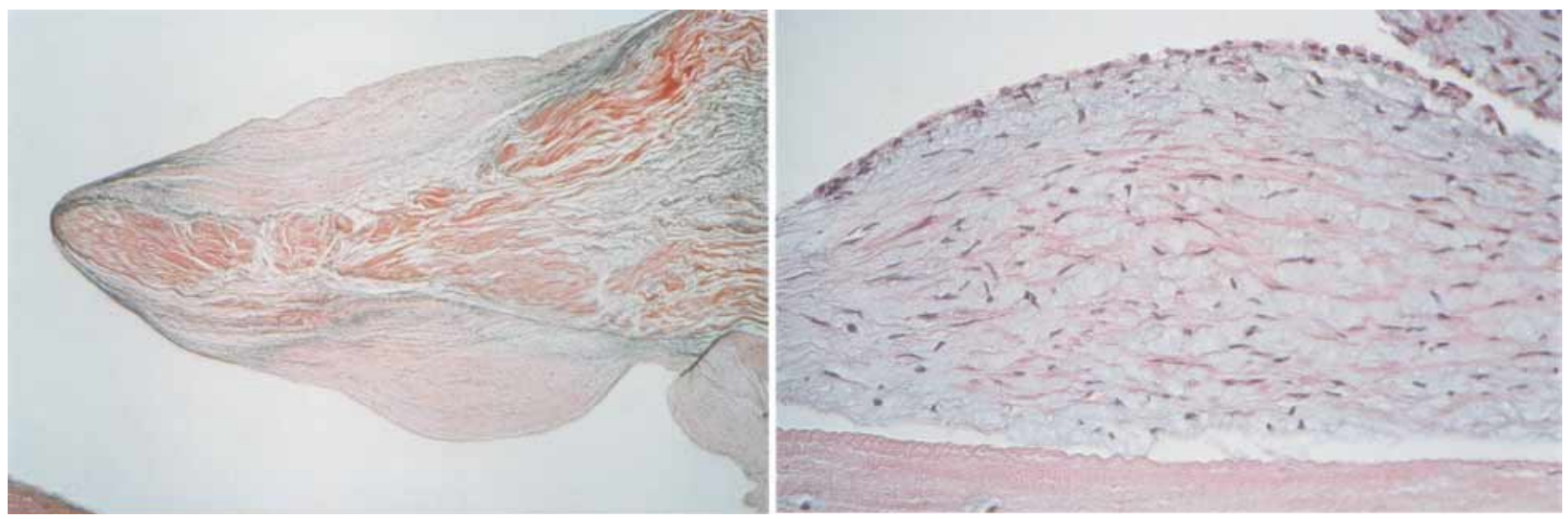

Figure 4. Photomicrographs of an excised valve from a patient with anorexigen-associated valvular disease. Left, Mitral leaflet (hematoxylin and eosin stain; $\times 360$ ). Right, High-power view of plaque (elastic-van Gieson stain; $\times 36$ ). There is smooth muscle cell hyperplasia in an abundant extracellular matrix, without evidence of inflammation or structural damage to the underlying structures. The plaques appear "stuck on."

use of fenfluramine has been pulmonary hypertension, ${ }^{13-15}$ although additional studies have also demonstrated that it may be neurotoxic in monkeys. ${ }^{16,17}$ Fenfluramine was approved for short-term treatment of obesity by the FDA in 1973 and has since been prescribed for an estimated 70 million patients worldwide for weight loss, with significant benefit compared with placebo. ${ }^{18-23}$ The D-isomer of fenfluramine, dexfenfluramine, has many of the same anorectic properties as racemic fenfluramine $e^{24-26}$; it too is associated with pulmonary hypertension ${ }^{27,28}$ and neuronal toxicity. ${ }^{17}$

Phentermine is a sympathomimetic amine that acts by interfering with central monoamine pathways through stimulation of dopamine release and has an inhibitory role in the metabolism of serotonin. ${ }^{29}$ It was approved for use in the treatment of obesity by the FDA in 1959 and has been used since as a single agent in the treatment of obesity. ${ }^{30,31}$ Phentermine, like other anorectics, has also been linked to development of pulmonary hypertension. ${ }^{32}$

In 1984, Weintraub and associates ${ }^{6}$ found that the same anorectic effects of fenfluramine and phentermine could be achieved with half doses of each drug used in combination. After this initial report, a clinical trial including 121 patients, who used the drugs for up to 3.5 years, confirmed the efficacy of combination therapy. ${ }^{33}$ Prescribing fenfluramine and phentermine in combination for weight loss became a common practice despite warnings such as that of Atkinson and coauthors, ${ }^{34}$ who wrote, "With such a sparse body of data in the literature, it is very hazardous to condone the growing practice by private practitioners in the United States of long term use of phentermine and fenfluramine."

Anorexigen-associated valvular disease is similar pathologically to the valvulopathy seen with carcinoid syndrome. This is not unexpected, however, since serotonin metabo- lism is implicated in the pathophysiology of each condition. Both carcinoid heart disease and anorexigen-associated valvular disease share many similarities with ergot and methysergide-induced valvulopathy. As seen in Table 3, the features of drug-induced valvulopathy overlap but are easily distinguished from those of rheumatic heart disease. In each of these conditions, patients may have symptoms of dyspnea, palpitations, or heart failure related to severe valvular regurgitation. Echocardiographic findings of leaflet thickening and tethering by shortened chordae can suggest a cause, but a detailed clinical history of diet drug use remains the most important element in the diagnosis of anorexigenassociated valvular disease.

Initial reports estimated that as many as one third of patients who have used these diet medications may acquire valvular disease; 2 recent studies suggest a lower incidence. Khan and associates ${ }^{39}$ found that $22.7 \%$ of patients treated with diet medications had valve abnormalities noted by echocardiography, compared with $1.3 \%$ among controls. Jick and coauthors ${ }^{40}$ found in their prospective case-controlled study that the incidence of clinically detected valve disease was only 35 per 10,000 patients who received fenfluramine or dexfenfluramine for more than 4 months.

On the basis of this experience, several points regarding surgical patients should be emphasized. First, even though we recognize that many other patients having anorexigeninduced valvulopathy have undergone surgery but were not reported to us or the FDA, it is clear that severe valvular regurgitation necessitating valve repair or replacement is rare; millions of patients have been exposed to diet drugs, but only a few will acquire valvular disease severe enough to require surgery.

Second, the patient history is the most important feature 
leading to diagnosis. Patients with unexplained valvular regurgitation should be queried regarding diet drug use, ergot use for migraine headache, rheumatic fever, or symptoms of carcinoid disease. The clinician should have a high index of suspicion in a previously healthy patient who presents with new symptoms of valve dysfunction and characteristic echocardiographic features.

Third, patients exposed to anorexigens may have associated pulmonary hypertension that seems out of proportion to the duration and severity of the mitral and aortic valvular regurgitation. In this series, pulmonary hypertension did not appear to affect early or late results of valve repair or replacement, and pulmonary hypertension may improve with discontinuation of medications and the repair or replacement of diseased valves.

Fourth, at operation, the gross morphologic characteristics of the valve may lead the surgeon to the correct diagnosis; the valves have a characteristic appearance and one that can be distinguished from that in rheumatic heart disease. In each of the included cases, the operative findings were similar, with thickening of the valves and chordae, which had a brilliant glistening white appearance. Histologic evaluation of excised valves also demonstrated a consistent picture, with smooth muscle proliferation in an abundant extracellular matrix, creating a "stuck on" appearance.

Fifth, in contrast to management of patients with carcinoid heart disease, in which the involved tricuspid valve exhibits variable degrees of stenosis mandating prosthetic replacement, valve repair is an option for patients with anorexigen-induced valvulopathy. In this study, patients who underwent repair had the same characteristic tethering of their posterior mitral leaflet and shortened chordae as did patients who required valve replacement. However, in the 4 patients who had a successful repair, the anterior mitral leaflets were still quite mobile. Placement of a posterior annuloplasty ring was sufficient to restore coaptation of the leaflet in 3 patients. In 1 patient, incision of the posterior medial papillary muscle, in addition to placement of a posterior annuloplasty ring, allowed a greater excursion of the posterior leaflet and restored coaptation. One patient who initially underwent mitral valve repair with the placement of an annuloplasty ring later required valve replacement, but we do not know with certainty whether this patient discontinued use of anorexigens or whether the initial repair was completely satisfactory. Because patients affected by this disease are primarily young women, valve repair in this fashion, when possible, seems preferable to valve replacement. Although valve repair is advocated in select patients with preserved mobility of leaflets, the severity of valvular disease in this group required valve replacement in the majority of patients (10/14). In only 4 patients was the degree of valve thickening and chordal shortening limited enough to allow repair. Although preservation of anterior leaflet mobility was not the most common finding, in the situation in which it is preserved, valve repair has worked well.

Finally, although the natural history of this disease is not completely known, early anecdotal reports give no indication that valvulopathy progresses once use of the medications has been stopped; indeed, there may be improvement in mild regurgitation over time. ${ }^{41}$ Additionally, we have had good results with mitral valve repair performed for anorexigen-associated valvular disease at our institution, and we have not seen progression of mitral valvulopathy on follow-up echocardiography.

In conclusion, it remains unclear how many patients will eventually acquire severe valvulopathy from exposure to anorexigens, but it is important for the cardiac surgeon to be aware of this unique disease and to understand that valve repair is a viable option for these young patients.

\section{References}

1. Methods of voluntary weight loss and control. National Institutes of Health, Office of Medical Applications of Research, Technology, Assessment Conference Statement. Bethesda (MD): 1992.

2. Kuczmarski RJ, Flegal KM, Campbell SM, Johnson CL. Increasing prevalence of overweight among US adults. The National Health and Nutrition Examination Surveys, 1960 to 1991. JAMA. 1994;272:205-11.

3. National Diabetes Data Group. Diabetes in America (NIH Publication No. 95-1468). 2nd ed. Bethesda (MD): National Institutes of Health, National Institute of Diabetes and Digestive and Kidney Diseases; 1995.

4. Colditz GA. Economic costs of obesity. Am J Clin Nutr. 1992;55(suppl):503S-7S.

5. Goldstein DJ, Potvin JH. Long-term weight loss: the effect of pharmacologic agents. Am J Clin Nutr. 1994;60:647-57.

6. Weintraub M, Hasday JD, Mushlin AI, Lockwood DH. A double-blind clinical trial in weight control: use of fenfluramine and phentermine alone and in combination. Arch Intern Med. 1984;144:1143-8.

7. Langreth R. Medicine: critics claim diet clinics misuse obesity drugs. Wall Street Journal. 1997 Mar 31;B1.

8. Connolly HM, Crary JL, McGoon MD, Hensrud DD, Edwards BS, Edwards WD, et al. Valvular heart disease associated with fenfluramine-phentermine. $N$ Engl J Med. 1997;337:581-8.

9. Beregi LG, Hugon P, LeDouraec JC, Laubie M, Duhault J. Structure activity relationships in CF3 substituted phenethylamines. In: Costa E, Garattini S, editors. Amphetamines and related compounds. New York: Raven Press; 1970. p. 184.

10. Garattini S, Buczko W, Jori A, Samanin R. The mechanism of action of fenfluramine. Postgrad Med J. 1975;51(Suppl 1):27-35.

11. Turtle JR, Burgess JA. Hypoglycemic action of fenfluramine in diabetes mellitus. Diabetes. 1973;22:858-67.

12. Wilson JP, Galton DJ. The effect of drugs on lipogenesis from glucose and palmitate in human adipose tissue. Horm Metab Res. 1971;3:262-6

13. Brenot F, Herve P, Petitpretz P, Parent F, Duroux P, Simonneau G. Primary pulmonary hypertension and fenfluramine use. Br Heart J. 1993;70:537-41.

14. Thomas SH, Butt AY, Corris PA, Egan JJ, Higenbottam TW, Madden BP, et al. Appetite suppressants and primary pulmonary hypertension in the United Kingdom. Br Heart J. 1995;74:660-3.

15. Abenhaim L, Moride Y, Brenot F, Rich S, Benichou J, Kurz X, et al, for the International Primary Pulmonary Hypertension Study Group. Appetite-suppressant drugs and the risk of primary pulmonary hypertension. N Engl J Med. 1996;335:609-16. 
16. McCann U, Hatzidimitriou G, Ridenour A, Fischer C, Yuan J, Katz J, et al. Dexfenfluramine and serotonin neurotoxicity: further preclinical evidence that clinical caution is indicated. J Pharmacol Exp Ther. 1994;269:792-8.

17. Ricaurte GA, Molliver ME, Martello MB, Katz JL, Wilson MA, Martello AL. Dexfenfluramine neurotoxicity in brains of non-human primates. Lancet. 1991;338:1487-8.

18. Ranquin R, Brems HM. Metabolic effects and anti-obesity action of fenfluramine in prolonged-acting form. Curr Med Res Opin. 1978;5:341-6.

19. Hossain M, Campbell DB. Fenfluramine and methylcellulose in the treatment of obesity: the relationship between plasma drug concentrations and therapeutic efficacy. Postgrad Med J. 1975;51(suppl 1):178-82.

20. Innes JA, Watson ML, Ford MJ, Munro JF, Stoddart ME, Campbell DB. Plasma fenfluramine levels, weight loss, and side effects. BMJ. 1977;2:1322-5.

21. Pietrusko R, Stunkard A, Brownell K, Campbell DB. Plasma fenfluramine levels, weight loss and side effects: a failure to find a relationship. Int J Obes Relat Metab Disord. 1982;6:567-71.

22. Douglas JG, Gough J, Preston PG, Frazer I, Haslett C, Chalmers SR, et al. Long-term efficacy of fenfluramine in treatment of obesity. Lancet. 1983;1:384-6.

23. Curzon G, Gibson EL, Oluyomi AO. Appetite suppression by commonly used drugs depends on 5-HT receptors but not on 5-HT availability. Trends Pharmacol Sci. 1997;18:21-5.

24. Finer N, Craddock D, Lavielle R, Keen H. Prolonged weight loss with dexfenfluramine treatment in obese patients. Diabetes Metab. 1987; 13:598-602.

25. Andersen T, Astrup A, Quaade F. Dexfenfluramine as adjuvant to a low-calorie formula diet in the treatment of obesity: a randomized clinical trial. Int J Obes Relat Metab Disord. 1992;16:35-40.

26. Guy-Grand B, Apfelbaum M, Crepaldi G, Gries A, Lefebvre P, Turner P. International trial of long-term dexfenfluramine in obesity. Lancet. 1989;2:1142-5.

27. Naeije R, Wauthy P, Maggiorini M, Leeman M, Delcroix M. Effects of dexfenfluramine on hypoxic pulmonary vasoconstriction and embolic pulmonary hypertension in dogs. Am J Respir Crit Care Med. 1995;151:692-7.

28. Weir EK, Reeve HL, Huang JM, Michelakis E, Nelson DP, Hampl V, et al. Anorexic agents aminorex, fenfluramine, and dexfenfluramine inhibit potassium current in rat pulmonary vascular smooth muscle and cause pulmonary vasoconstriction. Circulation. 1996;94: 2216-20.

29. Balcioglu A, Wurtman RJ. Effects of phentermine on striatal dopamine and serotonin release in conscious rats: in vivo microdialysis study. Int J Obes Relat Metab Disord. 1998;22:325-8.

30. Douglas A, Douglas JG, Robertson CE, Munro JF. Plasma phentermine levels, weight loss and side effects. Int J Obes Relat Metab Disord. 1983; 7:591-5.

31. Valle-Jones JC, Brodie NH, O'Hara H, O'Hara J, McGhie RL. A comparative study of phentermine and diethylpropion in the treatment of obese patients in general practice. Pharmatherapeutica. 1983;3:300-4.

32. Kokkinos J, Levine SR. Possible association of ischemic stroke with phentermine. Stroke. 1993;24:310-3.

33. Weintraub M. Long-term weight control: the National Heart, Lung, and Blood Institute funded multimodal intervention study. Clin Pharmacol Ther. 1992;51:581-5.

34. Atkinson RL, Blank RC, Loper JF, Schumacher D, Lutes RA. Combined drug treatment of obesity. Obes Res. 1995;3(Suppl 4):497S-500S.

35. Hauck AJ, Edwards WD, Danielson GK, Mullany CJ, Bresnahan DR. Mitral and aortic valve disease associated with ergotamine therapy for migraine: report of two cases and review of literature. Arch Pathol Lab Med. 1990;114:62-4.

36. Mason JW, Billingham ME, Friedman JP. Methysergide-induced heart disease: a case of multivalvular and myocardial fibrosis. Circulation. 1977;56:889-90.

37. Misch KA. Development of heart valve lesions during methysergide therapy. BMJ. 1974;2:365-6

38. Connolly HM, Nishimura RA, Smith HC, Pellikka PA, Mullany CJ, Kvols LK. Outcome of cardiac surgery for carcinoid heart disease. $J$ Am Coll Cardiol. 1995;25:410-6.

39. Khan MA, Herzog CA, St Peter JV, Hartley GG, Madlon-Kay R, Dick $\mathrm{CD}$, et al. The prevalence of cardiac valvular insufficiency assessed by transthoracic echocardiography in obese patients treated with appetitesuppressant drugs. N Engl J Med. 1998;339:713-8.

40. Jick H, Vasilakis C, Weinrauch LA, Meier CR, Jick SS, Derby LE. A population-based study of appetite-suppressant drugs and the risk of cardiac-valve regurgitation. N Engl J Med. 1998;339:719-24.

41. Cannistra LB, Cannistra AJ. Regression of multivalvular regurgitation after the cessation of fenfluramine and phentermine treatment. $N$ Engl J Med. 1998;339:771. 